\title{
INTERACTIONAL SOCIOLINGUISTICS IN CASUAL CONVERSATION OF GRADUATE STUDENT IN EFL CONTEXT: A PRAGMATICS STUDY
}

\author{
Betari Irma Ghasani ${ }^{\varpi}$ \\ Institut Agama Islam Negeri Salatiga (IAIN) Salatiga \\ $\square_{\text {betari.irma@iainsalatiga.ac.id }}$
}

\begin{abstract}
Communicating to others towards text which is as the result of discourse is everyone need. In producing text, there are some factors affected. Context which is one important influential factor needs to be analyzed. On the other hand, conversation as a media of exchanging meaning among the speakers are done in order to fulfill speaker aim. Pragmatics that learns meaning is seen as the best media to learn meaning produced by both speakers related to the context. By using interactional sociolinguistics suggested by Cutting (2002) and Gumperz (2015), as a part of conversation analysis in pragmatics, this approach takes pragmatic and sociolinguistics aspects of interaction, as well as adjacency pairs, turn-taking and sequences, giving importance to the way that language is situated in particular circumstances in social life. Based on the analysis done, it maps out that interactional talk claiming common ground with vague reference as a marker of both speaker friendship.
\end{abstract}

Keywords: Interactional Sociolinguitics, Casual Conversation, EFL

\begin{abstract}
Abstrak
Komunikasi dengan orang lain melalui teks lisan sebagai bagian dari wacana merupakan kebutuhan semua orang. Dalam memghasilkan sebuah teks, terdapat beberapa factor yang mempengaruhi. Konteks sebagai sebuah faktor penting perlu untuk dikaji. Selain itu, percakapan, sebagai sebuah media dari pertukaran makna di antara penutur terjadi untuk memenuhi tujuan dari penutur itu sendiri. Prakmatik yang mempelajari makna tersebut dipandang sebagai sebuah media untuk mempelajari makna yang diciptakan kedua penutur dan berkaitan dengan konteksnya. Menggunakan interactional sociolinguistics yang dikemukakan oleh Cutting (2002) and Gumperz (2015), sebagai bagian dari conversation analysis dalam pragmatiks, pendekatan ini menggunakan prakmatik dan aspek sosiolinguistik pada interaksi penutur, serta adjacency pairs, turn-taking dan sequences untuk memberikan penekanan bagaimana bahasa diposisikan pada kondisi umum di kehidupan bermasyarakat. Berdasarkan hasil analisis, dapat disimpulkan bahwa percakapan interactional menunjukkan bahwa walaupun terdapat vague reference sebagai penanda hubungan kedekatan pertemanan antar penutur.

Kata kunci: Interactional Sociolinguitics, Percakapan Kasual, EFL
\end{abstract}

\section{Introduction}

Communication with other people in our life is created through language and produce a text (Eggins, 1994). As the result of discourse, The term "text", according to Eggins (1994, p. 5), refers to "a complete linguistic interaction (spoken or written), preferably from beginning to end". When people produce a text, it is influenced by some factors around the text itself including context which can be seen through the selected words. Eggins (1994, p. 7) states that context is in text.

Text carries context as a part of it in which it was produced and, presumably, within which it would be considered appropriate (Eggins, 1994, p. 8). Context helps people in understanding the particular meaning of the word, phrase, etc (Richards \& Schmidt, 2010). Furthermore, the context may also be the broader social situation in which a linguistics item is used. The context in a conversation made by 
speakers might be different from one to others. It depends on the presentation patterns including gender, ethnicity, class and so on (Dimulescu, 2015).

Moreover, in our daily life, communication and interaction to others are needed for human beings as a social creature (Hapsari, 2011). As the result of communication and interaction, both speakers and hearer transfer and exchange information each other (Cruse, 2011, p. 18; Eggins, 1994; Eggins \& Slade, 1997). Furthermore, when the speakers talk through a conversation and produce a spoken text, actually they do not only exchange the information, but also show themselves to others (Dimulescu, 2015). They do communication for fulfilling their purposes such as buying, selling, finding information, getting jobs and etc. (Dimulescu, 2015).

On the other hand, people sometimes do conversation by talking simply for discussing simple issue. Talking simply for the sake of talking itself then is called as casual conversation (Eggins \& Slade, 1997, p. 6). They define casual conversation as "the kind of we talk we engage in when we are talking just for the sake of talking"(Eggins \& Slade, 1997, p. 8). Furthermore, they add that "we treat conversation as an exchange of meanings, as text, and recognize its privileged role in the construction of social identities and interpersonal relations" (Eggins \& Slade, 1997, p. 9)

As in casual conversation people talk a simple issue, it relates to the social environment surrounding motivated by interpersonal needs (Hapsari, 2011, p. 1). Doing casual conversation means maintaining social relationships among relatives, family, and friends (Dimulescu, 2015).

Some researches show positive effect in applying casual conversation for maintaining the relationship between speakers. A research done by Kathryn et al (2019) about casual conversations shows that it provides high public engagement with science in everyday spaces. Furthermore, by using casual conversation, opportunities for learning are also promoted (Stofer et al., 2019). Another study related to casual conversation is done in language teaching context. A study done by Hidayat (2019) suggests that casual conversation contributes in encouraging students to produce authentic utterance (Hidayat, 2019).

In doing casual conversation, there are also many factors influence the running of the text itself. In order to know the context of the conversation, pragmatics can be used as an alternative way to unveil the meaning and context of the conversation. Pragmatics is used to study the meaning of words in context, analyzing the parts of meaning that can be explained by knowledge of the physical and social world, and the socio-psychological factors influencing communication, as well as the knowledge of the time and place in which the words are uttered or written (Yule, 1996).

Furthermore, the speaker's meaning is dependent on assumptions of knowledge that are shared by both speaker, and hearer. The speaker constructs the linguistic message and intends or implies a meaning, and the hearer interprets the message and infers the meaning (Yule, 1996). In addition, speakers' intention is also influenced by their roles and position 
when the interaction takes places (Awang et al., 2010).

Some researches related to casual conversation mentioned above are done for analyzing the utterance only between the speakers. Combining research between casual conversation with pragmatics study for understanding the meaning of both speakers is still limited. Therefore, the study analyzing casual conversation in pragmatics perspective needs to be done.

In this study, interactional sociolinguistics is used for analyzing the casual conversation and conveying meaning. This approach takes into account the pragmatic and sociolinguistics aspects of interaction, as well as adjacency pairs, turn-taking and sequences, giving importance to the way that language is situated in particular circumstances in social life (Cutting, 2002).

Here, by using a recorded casual conversation done by students of postgraduate program, I am going to analyze interactional sociolinguistics which combines the conversation analysis approach, in that it studies the structural patterns of conversation, with a pragmatic approach which studying social interaction, and giving importance to context, function, and social norms, conventions and principles.

\section{Methods}

This study aims to investigate a casual conversation on pragmatics perspective by using interactional sociolinguistics approach. The structural patterns of conversation, context, function, and social norms, conventions and principles done by both speakers in the conversation were also being investigated in this study. Interactional sociolinguistics is an approach for interpreting what participants intend to share in their communication (Gumperz, 2015, p. 215)

In this study, I analysed a recorder casual conversation done by postgraduate students on a state university in the Academic Year 2015/2016 by using Gumperz (2015) theory on interactional sociolinguistics perspective.

The data in this study were spoken data as the main source. These data were qualitative since they contain information from individuals nt. By using this data, it is expected that they help us in giving a detail understanding and providing useful information io

In this study, as researcher, I did some roles including data collector and data analyst. As data collector, I gathered the conversation data from the speaker. Here, the media was recording. Furthermore, as data analyst, I tried to analyse the casual conversation.

Some procedures are done in this research including transcribing, reading, and analysing. As the first step, transcribing was done in order to write down the spoken text (recording file) into written text. In this step, I did transcribe by myself for following the speakers' flowing of information in their conversation. I listened to the recording several times in order to get the correct word.

After the transcribed written text version was ready, I read the text several times in order to catch the meaning shared and delivered by both speakers in their casual conversation. By reading the transcribed written text, it was expected that I would understand the text better. 
The next step is analysis. Here, I analysis the text after I read the transcribed written text.

\section{Results and Discussion}

This script is based on the transcription done of recorded casual conversation by two students of postgraduate programs on Semarang State University. Two students are talking about an assignment of a subject. The transcription can be seen on the Appendixes.

According to Cutting (2002, p. 28), conversation is discourse mutually constructed and negotiated in time between speakers; it is usually informal and unplanned. Cook (1989, p. 51) says that talk may be classed as conversation when it is not primarily necessitated by a practical task; any unequal power of participants is partially suspended; the number of the participants is small; turns are quite short; and talk is primarily for the participants not far an outside audience. Based on the definitions above, the conversation done by the postgraduate students can be defined as conversation.

In conversation, both speakers did turn taking for making conversation run well. They talked and discussed something in turn as stated by Cutting (2002, p. 29) that cooperation in conversation is managed by all participants through turn-taking.

The frequency of both speaker when they did conversation can be seen in the following table 2 below.

Table 1. Frequency of Turn Taking

\begin{tabular}{|l|c|}
\hline Speaker & Frequency \\
\hline 1 & $100(49.76 \%)$ \\
\hline 2 & $102(50.24 \%)$ \\
\hline Total & $202(100 \%)$ \\
\hline
\end{tabular}

Table 2 informs about how many turn taking taken by both speakers. Based on the table and diagram above, it could be observed that, overall, Speaker 2 did 102 turns while Speaker 1 did 100 turns. Although Speaker 2 raised 50.24\% instead of Speaker 1 who just took $49.76 \%$, this conversation still could be categorized as a balanced one. There was no dominated person who dominated in running the conversation. Both speakers were doing conversation and exchanging information in turn.

The conversation above happened between two colleagues in a university, Semarang State University who had known each other very well and they are together in a formal environment. It can be seen on the following dialogue

\begin{tabular}{|c|c|}
\hline Speaker 1 & $\begin{array}{l}\text { thank you. } \\
\text { Ok. I think our } \\
\text { class will start with } \\
\text { Mr. Joko right? }\end{array}$ \\
\hline Speaker 2 & What time is it? \\
\hline Speaker 1 & It is already 10 \\
\hline Speaker 2 & $\begin{array}{l}\text { a.m. } \\
\text { Ouh ... let's go to } \\
\text { class }\end{array}$ \\
\hline
\end{tabular}

The 'interpersonal relations' and the situational context have a significant influence on how the conversation flows since they share the same schemata, lecture. They know each other well enough to tease about their friend on line 192-195 as follows

$\begin{array}{ll}\text { Speaker } 2 & \begin{array}{l}\text { Yes, their own } \\ \text { dream. }\end{array} \\ \text { Speaker } 1 & \begin{array}{l}\text { Their own dream, } \\ \text { their own business } \\ \text { And we }== \\ \text { cannot...() }\end{array}\end{array}$




\section{Speaker $1==$ But please \\ remind me if I do \\ mistake [laughs] \\ Speaker 2 Yes, no no no, you \\ are the mistake. \\ Speaker [laughter] \\ $1 \& 2$}

Though Conversation Analysis says that the piece of talk showed that the speaker knowing each other well makes them talk casually, in a formal context and talking about less personal topics, the signs of their knowing each other well might not be obvious. The teasing done by speaker 2 were following by laughter and they were not dwelt on. Those evidences proved that they knew each other well enough as a friend. On the other hand, whereas discourse, pragmatics, and interactional sociolinguistics say that all background context influences what both speakers say, conversation analysis states that only some contexts are relevant in the understanding of talking between two speakers.

According to Cutting (2002, p. 68), if we come to this real-life conversation and try to make it fit the a priori exchange structure, we find that the conversation is far too 'chaotic' especially as there is one person with the role or status to initiate (as in teacher, doctor, quiz master) and the other respond, and nor does the situational context require it. Although Cutting proposes that kind theory, in this conversation there were some back channelings found as following:

$$
\begin{array}{ll}
\text { Speaker } 2 & \text { Yes, traditional food. } \\
& \text { Snack or food. } \\
\text { Speaker } 1 & \text { (i) Oh, snack or } \\
& \text { food? } \\
& \text { (ii) Yeah... em, it is } \\
& \text { such a } \\
& \text { challenging, } \\
& \text { another. Em, }
\end{array}
$$

another

challenging one.

Not to mention, there were some evaluating what the other speaker was saying. It can be seen as the following example.

$\begin{array}{ll}\text { Speaker 2 } & \begin{array}{l}\text { (i) And about UKK. } \\ \text { (ii) You know UKK? }\end{array} \\ \text { Speaker 1 } & \begin{array}{l}\text { [laughs].. I know.. Uji } \\ \text { Kompetensi Gu.. Eh? }\end{array} \\ \text { Speaker 2 } & \begin{array}{l}\text { No... Ulangan } \\ \text { Kenaikan Kelas }\end{array} \\ \text { Speaker 1 } & \begin{array}{l}\text { Oh, such a final..test } \\ \text { Speaker 2 }\end{array} \\ & \begin{array}{l}\text { Final test, final } \\ \text { semester test }\end{array}\end{array}$

Based on the data unfold, it can be seen that the chaotic nature of the conversation can be directly known and looked. We cannot talk of turn-taking in the sense of respecting transition relevance places.

Most of the time, conversation consists of two, or more, participants taking turns, and only one participant speaking at any time. Smooth transitions form one speaker to the next speaker. Though there were some full finished utterances produced by both speakers, the other half of the turns contained overlaps and interruptions. An example of overlaps and interruptions can be seen as follows

$$
\begin{aligned}
& \text { Speaker } 1 \text { How are you } \\
& \text { today? } \\
& \text { Speaker } 2 \text { (i) Oh, I'm fine. } \\
& \text { (ii) Ow.. how } \\
& \text { about you? } \\
& \text { Speaker } 1 \text { I'm so so... = } \\
& =E m \text {... } \\
& \text { Speaker } 2==\text { Terrible } \ldots \\
& \text { terrible ... }
\end{aligned}
$$

Based on the example above, it could be illustrated that overlaps and interruptions happened. Speaker 2 intended to answer 
speaker 1 who asked about speaker 2 condition by saying 'how are you?'. Unfortunately, before speaker 1 finished her utterance by saying "I'm so so", speaker 2 interrupted and said "terribleterrible" for continuing what speaker 1 wanted to say.

An analysis of the adjacency pairs showed that there were some neat pairing of utterances or turns happened on this conversation. An example of neat pairing both speaker was as follows:

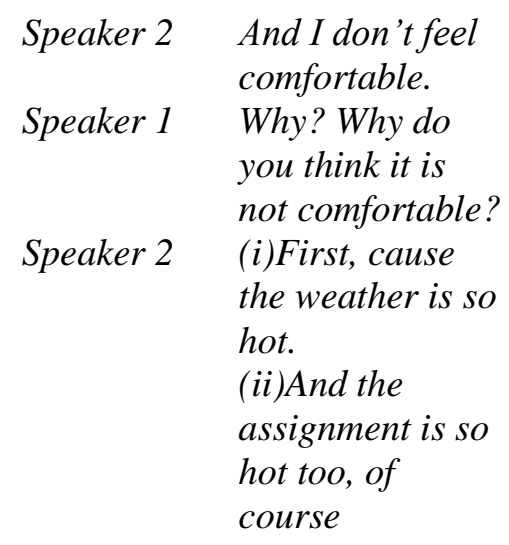

In turn 9, speaker 2 stated that he did not feel comfortable at that time. Speaker 1 responded neatly by asking the reason. By stated "Why? Why do you think it is not comfortable?", Speaker 1 wanted to know speaker 2 feeling. After hearing the question of speaker 1, speaker 2 answered it well by stating why he felt uncomfortable at that time.

Conversation analysts claim that as speakers are mutually constructing and negotiating their conversation in time, certain sequences, which are stretches of utterances or turns, emerge. These can be pre-sequence, insertion sequences, and opening and closing sequences. Analysis of the sequence of the conversation showed that there were opening and closing sequences on this conversation. Opening sequence on this conversation can be seen below

\begin{tabular}{|c|c|}
\hline Speaker 1 & Hallo, pak \\
\hline Speaker 2 & $\begin{array}{l}\text { Halo, } \\
\text { Speaker } 1 \text {... }\end{array}$ \\
\hline Speaker 1 & $\begin{array}{l}\text { How are you } \\
\text { today? }\end{array}$ \\
\hline Speaker 2 & $\begin{array}{l}\text { (i) Oh, I'm } \\
\text { fine. } \\
\text { (ii) Ow.. how } \\
\text { about you? }\end{array}$ \\
\hline
\end{tabular}

Speaker 1 and speaker 2 just met on their campus and they greet each other by saying hello. Furthermore, closing sequence on this conversation can be seen as follows:

\begin{tabular}{|c|c|}
\hline Speaker 2 & $\begin{array}{l}\text { What time is } \\
\text { it? }\end{array}$ \\
\hline Speaker 1 & It is already 10 \\
\hline Speaker 2 & $\begin{array}{l}\text { a.m. } \\
\text { Ouh ... let's go } \\
\text { to class }\end{array}$ \\
\hline Speaker 1 & $\begin{array}{l}\text { (i) Okay, } \\
\text { please.. . } \\
\text { (ii) bye.. maybe } \\
\text { another time } \\
\text { we will have } \\
\text { another } \\
\text { discussion.. }\end{array}$ \\
\hline Speaker 2 & $\begin{array}{l}\text { You come to } \\
\text { the class first. } \\
\text { Okay. See ya.. }\end{array}$ \\
\hline Speaker 1 & $\begin{array}{l}\text { See ya.. have a } \\
\text { nice day.. }\end{array}$ \\
\hline Speaker 2 & okay \\
\hline
\end{tabular}

Speaker 2 closed the conversation by saying okay after they greet each other before leaving and wet to the class to follow the lecture.

Returning to the relevance of the interpersonal relations and the situational 
context, interactional sociolinguistics point of view can be analyzed and contextualization cues point with imprecise reference to the knowledge that they have shared can be noticed. Cutting (2002, p. 33) states that interactional sociolinguistics focuses on the fact that social groups have their own ways of expressing meaning with their language.

Speaker 1 knew what assignment speaker 2 intended to state and discuss by saying narrative. Furthermore, speaker 2 used exophorix reference $i t$ to say that day and speaker 2 directly understood. This interactional talk claiming common ground with vague reference, whether there is a mini power struggle or not, is a marker of speaker 1 and speaker 2 friendship.

The result of this study confirms the theory proposedby Cutting (2002) and Gumperz (2015) that social groups have their own ways of expressing meaning with their language. The utterance produced by both speakers also shows their roles as a friend in their conversation. This result is in line with Awang et.al (2010) suggestion that the utterance is influenced by their roles when the communication takes place.

\section{Conclusions}

Interactional sociolinguistics combines the conversation analysis approach, in that it studies the structural patterns of conversation, with a pragmatic approach, studying social interaction, and giving importance to context, function, and social norms, conventions and principles. This approach takes into account the pragmatic and sociolinguistics aspects of interaction, as well as adjacency pairs, turn-taking and sequences, giving importance to the way that language is situated in particular circumstances in social life. Based on the analysis above it can be concluded that interactional talk claiming common ground with vague reference, whether there is a mini power struggle or not, is a marker of speaker 1 and speaker 2 friendship.

\section{References}

Awang, S., Maros, M., \& Ibrahim, N. (2010). An Analysis of a Discourse Using Interactional Sociolinguistics Approach. 2010 International Conference on Science and Social Research.

Cook, G. (1989). Discourse in language teaching: A scheme for teacher education. Oxford University Press.

Cruse, A. (2011). Meaning in Language: An Introduction to Semantics and Pragmatics (Oxford Textbooks in Linguistics). http://www.amazon.com/MeaningLanguage-Introduction-PragmaticsLinguistics/dp/0199559465

Cutting, J. (2002). Pragmatics and Discourse: A Resource Book for Students. Routledge.

Dimulescu, C. (2015). CASUAL CONVERSATION: A WAY OF BUILDING SOCIAL RELATIONSHIPS. 13th Conference on British and American Studies.

Eggins, S. (1994). An Introduction to Systemic Functional Linguistics. Pinter Publishers.

Eggins, S., \& Slade, D. (1997). Analyzing Casual Conversation. Cassell.

Gumperz, J. J. (2015). Interactional Sociolinguistics A Personal Perspective. In The Handbook of Discourse Analysis (pp. 215-228).

Hapsari, I. P. (2011). Analysing the Grammar of Casual Conversation: Enacting Role Relations. Language Circle, V, 1-11. 
Hidayat, D. N. (2019). Conversation Analysis and Its Implication to Language. TARBIYA: JOURNAL OF EDUCATION IN MUSLIM SOCIETY, 6(2). https://doi.org/dx.doi.org/10.15408/tj ems.v6i2.15138

Richards, J. C., \& Schmidt, R. (2010). Longman Dictionary of Language Teaching \& Applied Linguistics. Pearson.

Stofer, K. A., Rujimora, J., Sblendorio, D., Duqueney, E., Tatineni, M., \& Gaudier, and G. (2019). Casual conversations in everyday spaces can promote high public engagement with science. INTERNATIONAL JOURNAL OF SCIENCE EDUCATION, Part B. https://doi.org/10.1080/21548455.20 19.1670882

Yule, G. (1996). Pragmatics (Oxford). Oxford University Press. 